\title{
Making the second year count: embedding learning development in a progressive student journey
}

\section{Pat Hill}

University of Huddersfield, UK

\section{Amanda Tinker}

University of Huddersfield, UK

\section{Abstract}

In over a decade of working on embedding skills within the curriculum, it became apparent to us that the second or intermediate year was rather neglected in terms of intervention. Across the UK higher education sector, focus has been on supporting first year transition and final year projects (Yorke, 2015; Whittle, 2018). The aim of this paper is to explore a progressive approach to learning development within the curriculum which ensures that the second year is fully exploited in terms of bridging the gap between first and final years. Focus groups were used to investigate perceptions of students, subject specialists and learning developers and the subsequent issues are thematically analysed and discussed. Two case studies are then used to demonstrate the design of a curriculum which supports a collaborative and progressive approach to student learning in which learning developers can play a key role.

Keywords: Embedding skills; progressive learning development; student journey; curriculum design.

\section{Introduction}

UK higher education has embraced widening participation over the last twenty years but the complexity of dealing with such diversity in terms of learning development has presented many challenges. The initial reaction was that there was an imminent problem that would need fixing (Ivanic and Lee, 2006) and the response was to provide study 
support for those 'non-traditional' students that were seen to lack the necessary skills to succeed, following a typical remedial, deficit intervention which was retention oriented (Hill et al., 2010). In more recent years, a move away from this deficit approach has embraced a goal of inclusivity and sustainability aimed at learning development for all students, which is achievement-led rather than concentrating on those solely deemed 'at risk'. There has been a clear drive towards making UK higher education a breeding ground for independent, confident graduates with solid communication skills and other employability skills, such as critical thinking and problem solving, irrespective of their chosen discipline (Rust, 2016; Cacciolatti et al, 2017). The value of developing these skills within the discipline has been well documented in relation to student antipathy towards 'bolt-on' skills sessions (Wall, 2006; Wingate, 2006).

Hill and Tinker (2013) have previously explored ways of embedding skills and have suggested a set of 'generic principles' which are important considerations when integrating skills into the subject curriculum. During this research process, initiatives to embed skills within the curriculum were found to be useful but sporadic, and not developing students throughout their entire learning journey. There was a noticeable gap at intermediate level: the 'forgotten year' (Tobolowsky, 2008; Liverpool John Moores University, 2013; Milsom et al, 2015), which has received relatively little attention in research literature on UK higher education (Webb and Cotton, 2018). This article argues for, defines and demonstrates a progressive approach to learning development within the curriculum. It details an investigation into stakeholder perceptions of progressive learning development through collaboration with students, subject specialists and learning developers. These perceptions are also shared and disseminated by the creation of a video resource (Huddersfield University, 2014) accessible on a website (ALDinHE, 2014a). Case studies are then used to illustrate how this is subsequently realised in collaborative curriculum design and teaching practice.

\section{Embedding skills within the curriculum}

The need for ensuring that students are taught the necessary skills for studying in higher education and for employment has been largely accepted, but engaging students in such skills outside the curriculum has proved difficult. For example, Clughen and Connell (2011, p.333) maintain that academic writing 'needs to be contextualized within the discipline' or 
students may not recognise its value in their personal and professional development. This is important for all students, irrespective of their 'linguistic identities', as all students 'can benefit from an explicit and structured introduction to academic writing' (Hathaway, 2015, p.506). Hathaway also encourages writing development that:

is firmly framed as being concerned with the next stage of students' development and is not in any way remedial or compensating for any deficiency (Hathaway, 2015, p.507).

This move towards integrating aspects of learning development within the curriculum, however, is not without its challenges.

In an earlier project, these challenges were categorised as 'staff related', 'student related' and 'institution related.' Learning developers have highlighted: staff resistance to change, student diversity and the need for evidence of impact as particular challenges which may affect the way students learn. In facing these challenges, several factors have been identified for consideration when embedding skills. Figure 1 below illustrates these factors as a set of generic principles which may need to be considered in order to establish successful integration.

Figure 1. Generic principles for embedding academic skills (Hill and Tinker, 2013, pp. 10-11; ALDinHE, 2014b).

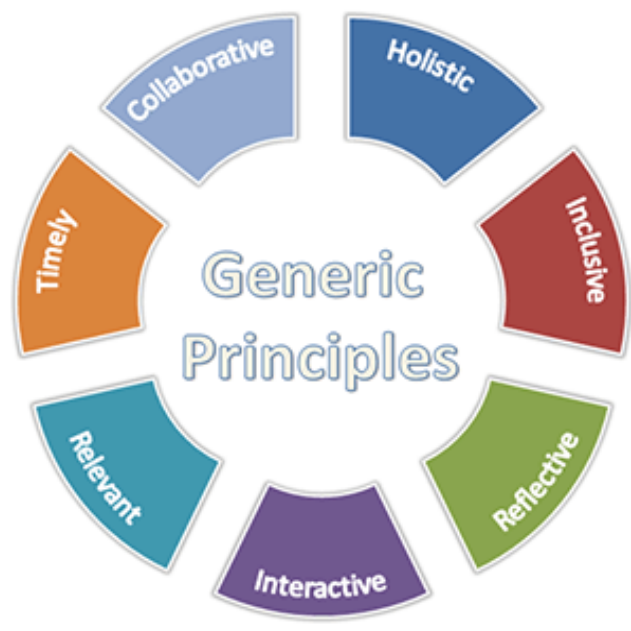

${ }^{1}$ For a more detailed analysis of these challenges and suggestions for solutions, please visit: http://aldinhe-embeddingskills.hud.ac.uk/node/60 
One of the major features identified above is a holistic approach to embedding learning development which not only takes into account the whole cohort and the whole programme but also the whole student journey. The complexity involved in developing student learning, not simply in terms of acquiring knowledge but also in terms of how to learn, has been well recognised:

Moving away from uncritical acceptance of knowledge to critically constructing one's own perspective is more complex than learning a skill set (Baxter-Magolda, 2006, p.50).

This is a gradual process which needs to be recognised and supported throughout the degree programme.

Compartmentalising the higher education system into modules with a focus on assessment has arguably made it more difficult for students to explore and to learn through making mistakes (Blake and Illingworth, 2015) or to make connections (Squires et al., 2009). It becomes more important, then, to establish a progressive learning environment which is 'scaffolded' and 'contextualised' (Cassar et al., 2012, pp. 35-45). Collaborating with subject specialists in context, learning developers have tried to ensure that skills are introduced in a timely manner at point of need. It is important to recognise, however, that there needs to be progression which ensures that students develop. It cannot be assumed that skills taught in the first year will be adequate throughout their degree programme, or even applied by students, or that the same skills sessions can simply be repeated.

\section{Progressive learning}

One of the main ideas to evolve from our initial work on embedding was a recognition of what is known in the United States as 'the Sophomore Slump' (Hunter et al., 2010). In the last few years:

it has been recognised in the USA that second year students have substantial needs but receive the least attention of all undergraduates (Yorke, 2015, p.4). 
US research has shown that students often experience a loss of engagement, struggle to manage a smooth transition into year two and, consequently, to get the best out of their intermediate level of undergraduate study (Gump, 2007). Gump acknowledges that there had previously been a great deal of research on the first year transition into higher education that led to many interventions, many of them particularly aimed at retention. He also points out that research suggests that these interventions may actually simply postpone the emergence of issues until the second year when there is far less support available (pp. 111-112). The system in the United States differs from the UK, in that American students have a general introduction to higher education before the process of choosing a 'major', but UK universities have also focussed more attention on the first year and are beginning to recognise similar issues (Scott and Cashmore, 2012). Liverpool John Moores University (2013) were one of the first to highlight the situation in the UK with a HEFCE project 'The Forgotten Year: Tackling the Second Year Slump' (Thompson et al, 2013). Following an intervention which introduced additional on-line support for second year students (see Skills@Library, University of Leeds, n.d.), Whittle concludes that:

Further longitudinal studies will be required to determine whether a slump in second-year satisfaction or performance is a consistent finding nationally (Whittle, 2018, p.98).

Statistics from a previous project at the University of Huddersfield showed that intermediate students were less likely to seek help individually from learning developers and that taught sessions were also less frequent (see Figure 2 below). 
Figure 2. Total percentages of tutorials and taught session delivery in the Schools of 'Art, Design and Architecture' (ADA) and 'Music, Humanities and Media' (MHM) 2010-2011.

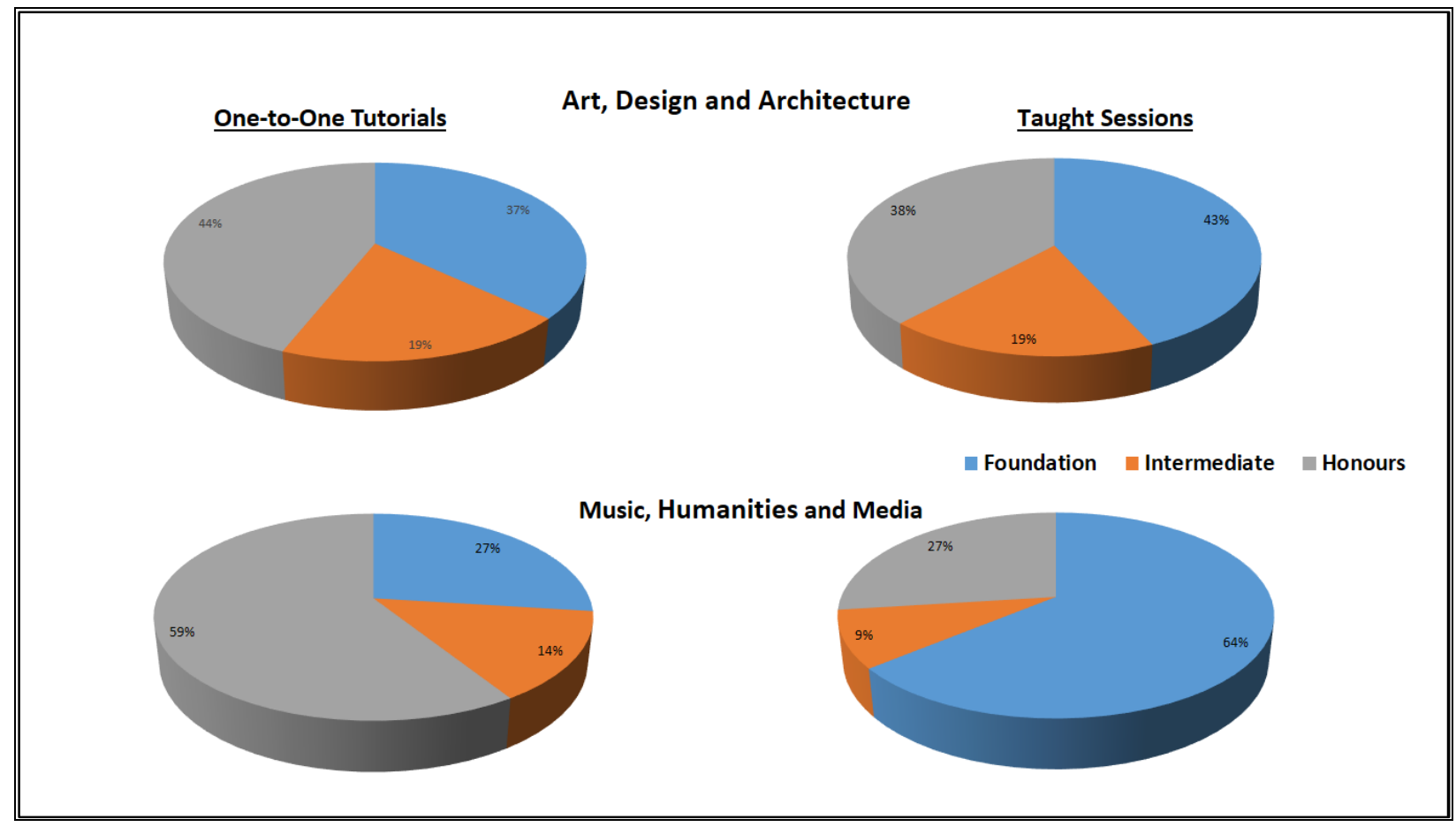

Our previous research had also highlighted that skills assessed at intermediate level were often not specifically taught. A project was then initiated to ascertain whether skills could be embedded more holistically and progressively, across the entire student journey. The idea of year two being a 'bridge' between initial and final year needed to be explored and how the second year could be enhanced to ensure student progression.

\section{Method}

Focus groups have become an established method for capturing perceptions from stakeholders (Krueger and Casey, 2009, p.3). Within the Schools of 'Art, Design and Architecture' and 'Music, Humanities and Media', six focus groups and one interview were conducted separately with subject staff, students and learning developers to explore ideas, perceptions and experiences about progressive learning development and the second year of study. It was decided to separate the groups by role so that participants could feel confident in expressing their honest views, aiding the validity of the research. Care has to be taken in using pre-existing groups, as hierarchical relationships, such as tutor-student, 
may 'inhibit the frank exchange of ideas' (Barbour, 2007, p.67). It was anticipated that a further focus group of learning developers would offer a more objective perspective. All participants had self-selected to attend. In line with Barbour (2007), it was decided to not simply ask questions of the focus group but to provide 'stimuli' in the form of posters for 'their usefulness in breaking the ice' and 'capacity to stimulate discussion' (p.84). Rather than simply record individual participant responses, as per traditional focus groups, the group were given an activity which encouraged them to debate and reach consensus on the most pertinent issues (Colucci, 2007, p.5). The design of the activity stimuli not only ensured that the group provided relevant information but also allows for future replication, contributing to reliability. Posters were designed by the project team appropriate for the three different types of stakeholder/focus group and each was given the activity to map progression, as they perceived this, across the three years of study (see Figure 3 below for an example).

\section{Figure 3. Example of workshop poster.}

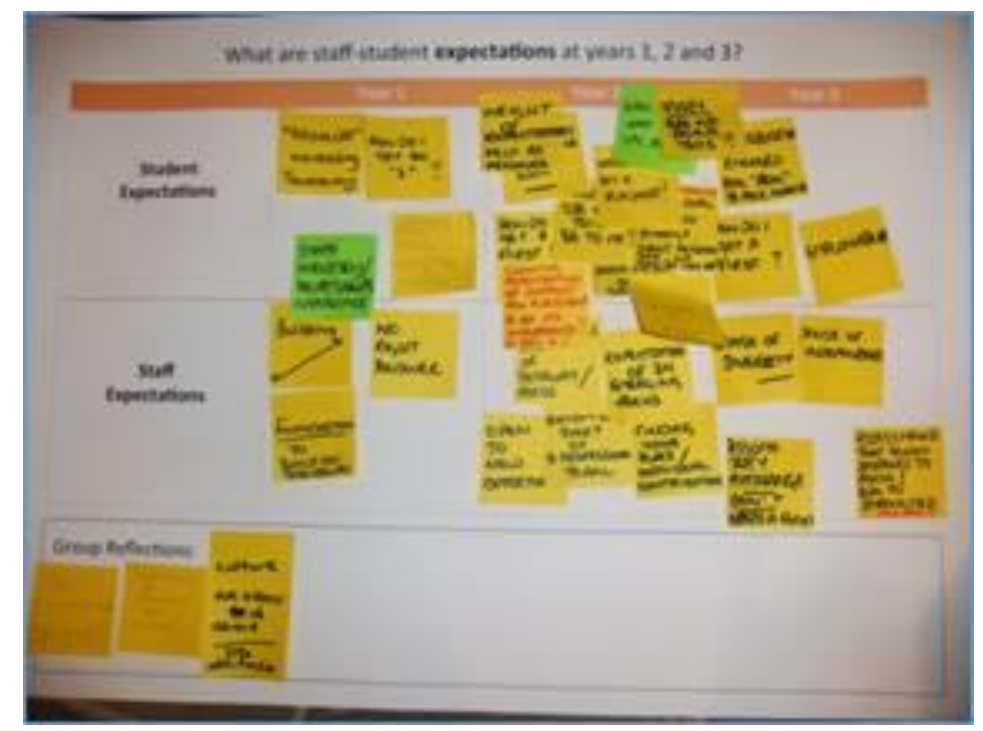

The summary discussions were audio recorded and, along with individual perspectives written on the posters, this became the data set for transcription and analysis. Ethical consent to use the data was granted by all participants.

Two subject-staff focus groups, each with 20 participants were conducted. These were University of Huddersfield academic staff from different disciplines who were attending teaching and learning events and self-selected to attend our workshops. Within these, 
participants were organised into four different groups and asked to discuss and map issues and experiences from first to final year of study according to broad themes:

- Staff-student expectations for each year.

- Curriculum content, assessment and feedback.

- Different working environments, internal and external factors.

- Pastoral care and Personal Development Planning (PDP).

Each group was given one of above areas to consider and provided with 3-5 questions, devised by the project team to prompt discussion and facilitate the mapping exercise. Participants were also provided with an opportunity to record their individual and overall group reflections relating to progression. Each group then, in turn, was asked to report the key elements of their discussion, which was recorded and later transcribed, together with the photographing and noting of issues raised on the mapping posters.

Two student focus groups were conducted, one within each School, each with 6 intermediate-level participants. Students were given a list of graduate skills to consider and were asked to write on post-it notes in response to the question 'How can we develop student skills?' and a series of more specific questions in relation to years one, two and three of study. The group were then asked to talk through their poster and this feedback was audio recorded for analysis. Two follow-up focus groups were attempted with final year students; although only two and one attended respectively, this provided some very rich data as their view of the progress was informed and reflective.

The final focus group was with 25 learning developers from a variety of UK universities who attended an ALDinHE conference workshop (Bailey et al., 2013). The participants were split into 4 groups and asked to consider the question 'How can we develop skills progressively?' Again, mapping posters were used and participants were asked to consider themes of 'expectations', 'experiences' and 'evolution', considering how skills can be integrated progressively, making the most of the intermediate year. As previously, groups were asked in turn to report key elements of their discussion and this feedback was similarly recorded and transcribed. 
The qualitative data from the above focus group activities and transcribed audio was then analysed for emergent themes. These themes were generated through manual, inductive 'framework analysis' (originated by Ritchie and Spencer, 1994) according to Krueger and Casey's definition of 'key concepts' (2009, p.125). The system:

allows themes to develop from the research questions and from the narratives of research participants (Rabiee, 2004, p.657).

However, as Braun and Clarke (2006) point out, researchers play an active role in identifying patterns and in this small scale investigation, our focus gradually moved towards selecting themes which reflected tensions arising from different stakeholder perceptions (MacLellan, 2001).

These perceptions from the focus group analysis have been shared in the form of thematic videos added to the ALDinHE website resource on embedding skills (ALDinHE, 2014a), where a new section on progressive learning was developed (see Hill and Tinker, 2013, for a description of the original website development project). The focus groups excerpts were extracted using open source audio recording and editing software (Audacity, 2018) and thematic videos were created, together with an accompanying context and rationale (see Figure 4 below).

Figure 4. Screen shots embedding skills resource (ALDinHE, 2014a; Huddersfield University, 2014).
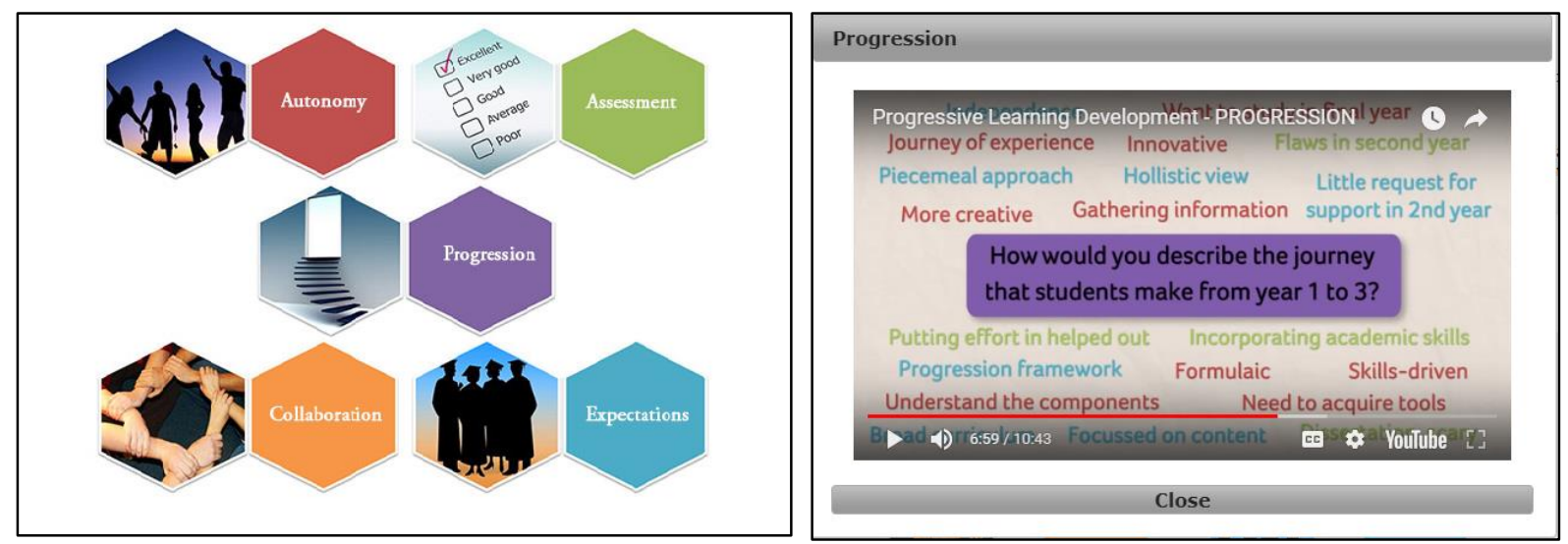

Technical assistance was sourced from a recent graduate and his company, Fifth Planet Productions (2016). The videos were organised in terms of question prompts, which were 
devised specifically; the original voices can be heard, followed by visual keyword summaries, which were colour-coded according to staff, student and learning developer voices (see Figure 4). The combination of these three different stakeholder views have provided both internal and external perspectives, supporting validity and giving the opportunity to extract relevant and interesting themes, which are disseminated in the current paper and through the embedding skills resource shown above. The findings below summarise these key themes and offer a view of progression in learning, illustrated through these participant 'voices'.

\section{Focus group findings and analysis}

Five key themes were identified from the analysis: Assessment, Autonomy, Collaboration, Progression and Expectations. Subject staff, learning developer and student perceptions of the student learning journey, documented through focus groups and interview, are captured in the following 'content-analytic summary table' (Miles and Huberman, 1994, p.183). The voices represented in Table 1 below illustrate different perceptions of a multi-layered learning journey demonstrating the inherent complexity and conflict. The challenge for learning developers is to acknowledge these tensions and help to design curricula resources which balance these expectations. 
Table 1. Content-analytic summary table of subject staff, learning developer and student perceptions.

Colour Code: Subject Staff; Student; Learning Developer.

\begin{tabular}{|c|c|c|c|}
\hline Theme & Year 1 & Year 2 & Year 3 \\
\hline Autonomy & $\begin{array}{l}\text { Spoon-fed } \\
\text { Need more pastoral care } \\
\text { See staff as school teachers } \\
\text { Modelling } \\
\text { Need to acquire tools } \\
\text { Guided reading tasks needed } \\
\text { Some students want spoon feeding; } \\
\text { some want challenge } \\
\text { Need direction } \\
\text { Knowledge acquisition vs } \\
\text { independent leaming expertise }\end{array}$ & $\begin{array}{l}\text { Become adults } \\
\text { Gain Confidence } \\
\text { Responsibility for their own } \\
\text { learning } \\
\text { Not reminded } \\
\text { Left to it } \\
\text { Assumption that we know what } \\
\text { we were doing. } \\
\text { Less involvement }\end{array}$ & $\begin{array}{l}\text { Peer to peer } \\
\text { Staff as collaborators } \\
\text { Need more hands on help } \\
\text { Should be autonomous but } \\
\text { more input from LD }\end{array}$ \\
\hline Expectations & $\begin{array}{l}\text { Students want 'right' answer } \\
\text { Challenge -need to be more } \\
\text { academic } \\
\text { Guidance/reminders } \\
\text { More explanation of difference in HE } \\
\text { needed } \\
\text { Need monitoring } \\
\text { Seemed irrelevant } \\
\text { Easy year } \\
\text { Could get away with it } \\
\text { Students expect to be told what to } \\
\text { read } \\
\text { Staff just expect them to get on with } \\
\text { it }\end{array}$ & $\begin{array}{l}\text { Identify strengths } \\
\text { Excite/challenge } \\
\text { More demanding } \\
\text { Separate weak from strong } \\
\text { Think they can do it from what } \\
\text { they did in Year } 1 \\
\text { Bit of a shock } \\
\text { Workload heavier than } \\
\text { expected } \\
\text { More deadlines } \\
\text { Less intervention } \\
\text { More realistic }\end{array}$ & $\begin{array}{l}\text { Get engaged } \\
\text { Should need even less help } \\
\text { Need more hands on help } \\
\text { More independent } \\
\text { Hard work/stress }\end{array}$ \\
\hline Collaboration & $\begin{array}{l}\text { Delicate balance } \\
\text { Individual vs. team } \\
\text { Competitive } \\
\text { Initially groupwork } \\
\text { Expected more group work } \\
\text { Easier on your own } \\
\text { PAL Mentors help }\end{array}$ & $\begin{array}{l}\text { Self-focussed } \\
\text { Mentoring } \\
\text { Sharing tasks } \\
\text { Inadequate feedback for group } \\
\text { work so individuals 'learned } \\
\text { nothing' } \\
\text { Need for Staff/LD/Student } \\
\text { consultations } \\
\text { Peer mentors improve their } \\
\text { own skills }\end{array}$ & $\begin{array}{l}\text { Developing into Teamwork } \\
\text { Professional } \\
\text { Mutual respect } \\
\text { Networking skills are } \\
\text { important } \\
\text { Dissertation Club }\end{array}$ \\
\hline Assessment & $\begin{array}{l}\text { Can take risks } \\
\text { Marks Marks Marks } \\
\text { How can I get an A? } \\
\text { Need clear standards of quality } \\
\text { Not personal } \\
\text { Variety in development } \\
\text { Year one doesn't count } \\
\text { Group marks are unfair } \\
\text { Staff have unrealistic expectations or } \\
\text { too basic to develop students }\end{array}$ & $\begin{array}{l}\text { Honesty of critique } \\
\text { Opportunity to explore but } \\
\text { counts } \\
\text { Strategic } \\
\text { Taking risks? } \\
\text { Making mistakes is a learning } \\
\text { process } \\
\text { Grading tariff does not reflect } \\
\text { amount or difficulty of work } \\
\text { Too many deadlines too close } \\
\text { Should start to see patterns } \\
\text { and make links } \\
\text { Risk averse }\end{array}$ & $\begin{array}{l}\text { Professional } \\
\text { Self-assessor } \\
\text { Models \& exemplars needed. } \\
\text { Fewer but larger projects } \\
\text { make time management } \\
\text { easier but adds to pressure of } \\
\text { assessment } \\
\text { Higher level expected }\end{array}$ \\
\hline Progression & $\begin{array}{l}\text { Clear narrative } \\
\text { Formulaic/acquire skills } \\
\text { Took it too easy } \\
\text { Bit of a free ride } \\
\text { Broad curriculum - focus on skills } \\
\text { Piecemeal approach }\end{array}$ & $\begin{array}{l}\text { Fresh start } \\
\text { Content driven } \\
\text { More creative } \\
\text { More guidance about what's to } \\
\text { come } \\
\text { Flaw in the second year } \\
\text { Making connections } \\
\text { Focus on content } \\
\text { "scale it up" }\end{array}$ & $\begin{array}{l}\text { Innovative } \\
\text { Focussed } \\
\text { Leamt more skills in } 3^{34} \text { year } \\
\text { but should be throughout. } \\
\text { Holistic outlook of subject. } \\
\text { Progression framework } \\
\text { needed. } \\
\text { Skills taught in YR3 rather } \\
\text { than 'scaffolded' throughout }\end{array}$ \\
\hline
\end{tabular}




\section{Autonomy and expectations}

In relation to the themes of autonomy and expectations, there are clear conflicts between staff and students where first year students expect to be directed to the 'right answer' and staff are trying to encourage students to begin to acknowledge that there 'might be multiple ways of addressing issues and problems' (Subject Staff Focus Group). In contrast, some staff perceive themselves as 'spoon-feeding' first year students, and learning developers felt that this was what students wanted. In terms of writing, students explained that 'what you wrote at A' level was alright, but when you get to university what they are looking for is completely different' (Student Focus Group). Learning developers mentioned 'quite a variation' amongst academics' expectations around writing, particularly in relation to fostering critical analysis in first year versus description. Students also felt that not enough had been said about the differences in expectations between further and higher education. They suggested that whilst they were required to write every week at school or college, 'the difference was not really explained' so that whilst expecting 'more hitting the ground running' they ostensibly had less work and regarded it as 'an easy year'. This was linked by one student to accountability as he pointed out that students could omit the reading without penalty unless there was a direct associated task. Another student said that he was given 'three months to do an essay' but that 'we were never really reminded that much or pushed to do it' so even though the assessment was in the module handbook from week one, priority was given to practical work and it came as a surprise to them when the tutor mentioned the essay the week before the deadline.

Even though they were given reading lists, students expected to be told exactly what to read. Whereas some staff did give directed reading, which students appreciated (Student Focus Group), other staff expected students to 'just get on with it' (Learning Developer Focus Group). A lack of consistency and communication was a fundamental issue with students but staff appeared to feel that students needed to be more proactive and responsible for their own learning. Although they can never be a fix-all for the issues around differing staff and student perceptions, there does appear to be a role for learning developers in brokering and managing expectations on both sides. Collaboration with subject staff and involvement in curriculum planning can ensure timely interventions.

A related area of conflict in terms of the themes of autonomy and expectations was where second and third year students expected more help with more demanding work, whereas 
staff seek to step back in order to foster autonomy. Students explained 'that we expected more, like, help...but when we got to year two, we had to try and, like...learn it ourselves, really, and just kind of wing it' (Student Focus Group). Staff, however, said that 'they [students] feel they need real support individually to help them get into their groove whereas staff think that we are going to let go because you're more independent and we want to give you more space' (Subject Staff Focus Group). Learning developers also identified a conflict between the need for knowledge acquisition and making room for the development of autonomous learners with a wider skills base. As identified earlier, there could be an opportunity for learning developers to bridge the gap so that staff can confidently focus on content, in the knowledge that students will be able to access relevant support, for example, in the form of directed and timely workshop interventions. The dearth of such interventions in the second year was noted by learning developers and is discussed further under the theme of progression.

\section{Collaboration}

In terms of collaboration, subject staff felt that there was a 'delicate balance' between first year students working as individuals and as part of a team and their inclination was to be competitive. Even when students were working together, staff perceived this as students working alongside each other rather than as a cohesive team. Staff felt that students began to share ideas and tasks more readily in year two. However, it was not until year three, often following a work placement, that this became true teamwork, with peer to peer support and students viewing staff as collaborators not just teachers. Generally, first year students, although they expected more teamwork, regarded it as onerous and suggested that 'it's a lot easier to do it on your own'; part of the issue is the perception of unfair assessment. One student admitted that he had done far less work than another student, yet still achieved the same grade and perceptions of assessment are discussed further below. Collaboration between students through peer mentoring and peer assisted learning was identified by learning developers as a positive solution both for those needing support and those who supported. Students can be guided by those who have been through the process and mentors can develop graduate skills in leadership and communication. Learning developers also suggested year three support mechanisms such as social media and dissertation clubs. 


\section{Assessment}

Assessment was a theme which students felt quite strongly about and staff perceived them to be driven primarily by grades, particularly in the first year: 'How do I get an A? How do I get a First?' Other first year students, however, were unconcerned about grades as 'Year one doesn't count' (Student Focus Group). In retrospect, the year three student said that although he found the first year 'quite simple', he felt that his first year effort in developing academic writing had helped him throughout his degree whereas students who coasted in the first year struggled in the second and third years. He felt that there needed to be more formal assessment of skills so that students realised the importance of it. Learning developers were also concerned that in an effort to break down challenging concepts, staff avoided 'long written assignments which doesn't necessarily help prepare them because the first year then becomes very basic' (Learning Developer Focus Group). This then causes a dissonance between first and second year with some students unprepared for the increased demands of year two. Intermediate students felt that there were too many deadlines and were conscious that these would count towards their degree classification, so even though staff felt that year two students should be willing to take risks and know that 'making mistakes is a learning process' (Subject Staff Focus Group) the students were felt to be 'risk averse...everything counts so students become strategic' (Learning Developer Focus Group). Both year two and year three students commented on the need for models or exemplars to make it clearer what was expected of them so that 'you know you're going on the right lines'. Some students were also concerned that the marks awarded did not always reflect the amount of work necessary to complete a task and that they were sometimes unsure of how and why marks were allocated. This was despite staff providing written criteria and rubrics for each assessment. Learning developers can have a useful role in providing models and helping students to interpret criteria and to show how they can be applied and how this links to tutor feedback. These different perceptions and challenges reflect the complexity in accommodating the needs of a diverse student population and ensuring that each student has a clear sense of their own progression from fresher to graduate. 


\section{Progression}

The overarching theme of progression has been one that has driven the current project and, in evaluating the voices of these stakeholders, it has become apparent that the learning developer can have a vital role in bridging gaps in perception, mediating between subject staff and students. Subject staff expressed a 'clear narrative' of the student journey from acquiring the basic 'tools' and communication skills, through 'knowledge gathering' and 'making connections' in year two towards the 'holistic outlook' necessary in year three, as students follow their own 'personal journey.' Students, however, were often failing to see this progression; first year students found year one 'a bit of a free ride' (First Year Focus Group), not realising the value of developing, honing and the potential to transfer these skills. Interestingly, an issue for second year students was repetition, where they felt that the reiteration of skills taught in the first year was unnecessary, for example the use of the library's electronic resources database: 'I think... once you've done it you kind of know... how to use Summon and things like that' (Student Focus Group). A final year student warned that 'quite a few people suffered in first year - they're paying for it now... putting in effort in first year helped me in third year' (Final Year Student Interview). He felt that 'there's a flaw in the second year' as the 'third year skills should be enhanced from first year,' with even 'some sort of compulsory component that keeps going through the years'. This contrast in subject staff and student perceptions is a clear issue for learning developers who need to ensure that their interventions are timely, at the right level and are fostering development and progression in terms of undergraduate and graduate skills.

Timely interventions, however, are not always in the control of learning developers, who identified a lack of requests from subject specialists in the second year to help enhance skills: 'almost like the preparation happened in the first year; they can get on with it and then there's the third year'. They called for academic skills to be 'scaffolded in a more progressive way', rather than 'strategically focused in year two around particular types of assessments...they haven't done one of these yet, come in and help them'. Ideally, there needs to be a move away from a 'model of seconded learning development as needed' towards a collaborative and consultative role which takes course and curriculum design into account. Learning developers also suggested that this might also take the form of a 'progression framework' which makes skills 'more explicit'. In many cases this is typically accomplished through reflective, personal development planning portfolios in which 
students can articulate their learning and staff can map clear progression of the student journey and development of graduate attributes (Higher Education Academy, 2018) This concept of a progression framework has formed the basis of collaborative curriculum development.

\section{Curriculum design and delivery for progressive learning development}

In response to the above focus group findings, we are now working with subject teams to embed the teaching of academic skills progressively across all years of study. The previously mentioned generic principles (see Figure 1, p.3) have been useful as a basis for an effective embedding strategy. In terms of collaboration, there have been planning meetings with subject staff and other stakeholders, including librarians and learning technicians. Embedded, rather than separate, skills development sessions mean that all students have the opportunity to be included and have access to learning developer expertise throughout their programme. A holistic view of the programme ensures that sessions are not simply repeated but offer enhancement, focusing on increasing demands of the subject discipline. Discussions with stakeholders allow for timely and relevant interventions throughout each year of study. Sessions are designed to be interactive and to encourage reflective practice. As learning developers, we share ideas and teaching resources across the different Schools whilst fulfilling discipline specific requirements in order to engage students.

Although each School works differently, the core content of what we offer can be seen in Figure 5 below. This has been used as a discussion tool with course teams in order to facilitate curriculum planning that accommodates the entire student journey and emphasises the need for progressive learning development throughout all three years of study, including the 'forgotten' second year. This generic structure is then tailored to the needs of the subject discipline context. 
Figure 5. Curriculum development tool.

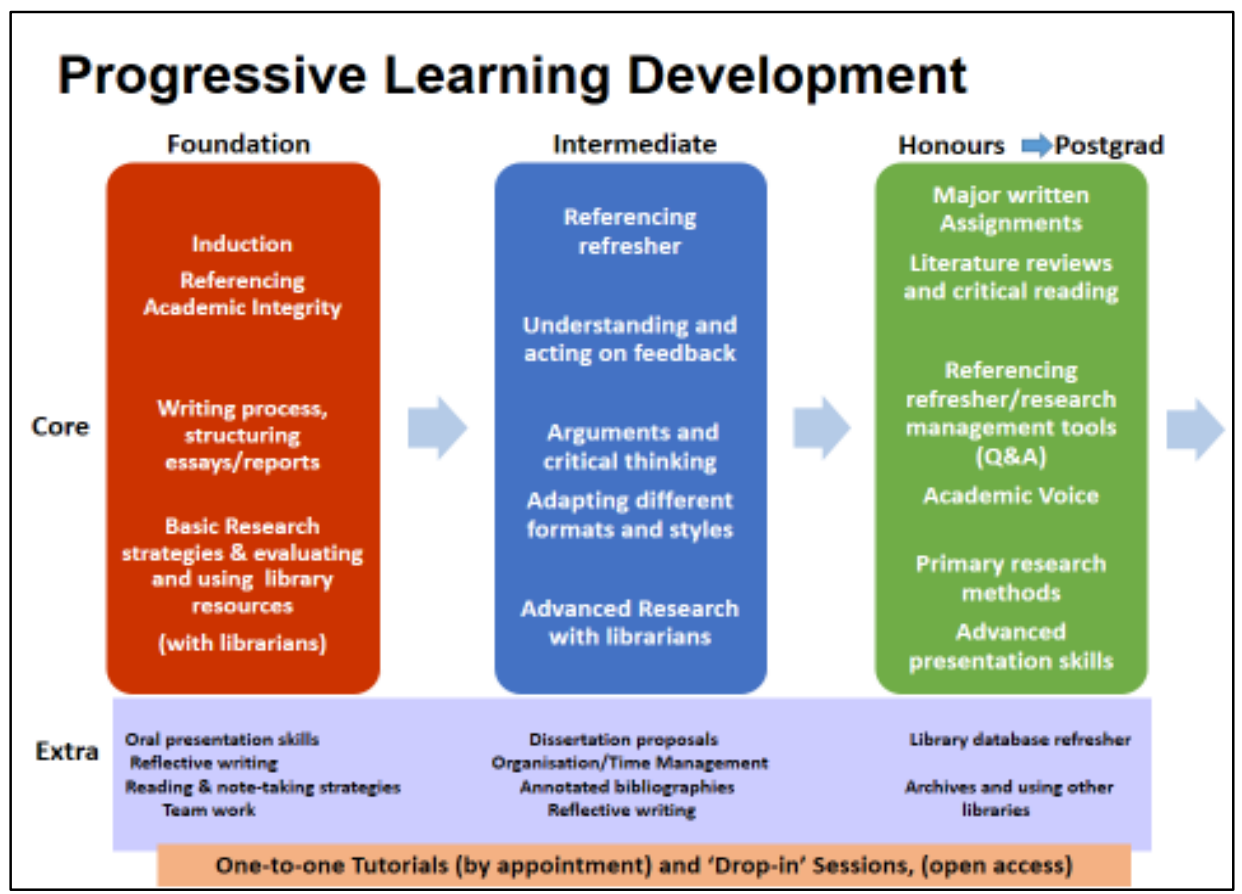

Tables 2 and 3 below illustrate specific subject discipline case studies in History and Photography:

Table 2. History case study.

\begin{tabular}{|c|c|c|c|}
\hline & Foundation & Intermediate & Final \\
\hline Module Title & Becoming a Historian (no credits) & Research Skills (20 credits) & $\begin{array}{l}\text { History Dissertation \& } \\
\text { Graduate Futures ( } 40 \text { credits) }\end{array}$ \\
\hline $\begin{array}{l}\text { Type of } \\
\text { Assessment }\end{array}$ & $\begin{array}{l}\text { Formative tasks related to other } \\
\text { module assessments }\end{array}$ & $\begin{array}{l}\text { Annotated Bibliography (1000) (Formative) } \\
\text { Essay }(2,500) \\
\text { Dissertation proposal and critical source } \\
\text { evaluation (1500) }\end{array}$ & $\begin{array}{l}\text { Poster } \\
\text { Research Fair presentation } \\
\text { Dissertation (12,000 words) }\end{array}$ \\
\hline Session Title & $\begin{array}{l}\text { Research Skills } \\
\text { Oral Presentations } \\
\text { Essay Writing } \\
\text { Referencing } \\
\text { Document analysis } \\
\text { Reflection } \\
\text { Understanding Feedback } \\
\text { Exam Revision }\end{array}$ & $\begin{array}{l}\text { Research Skills (Archives) } \\
\text { Critical reading } \\
\text { Annotated Bibliography } \\
\text { Making an effective pitch } \\
\text { Digital Sources } \\
\text { Historiographical essays } \\
\text { Reflection } \\
\text { Writing a proposal }\end{array}$ & $\begin{array}{l}\text { CVs \& Job search } \\
\text { Time management \& organisation } \\
\text { (TM\&O) } \\
\text { Advanced Research skills } \\
\text { Referencing refresher } \\
\text { Practical Poster session } \\
\text { Formatting your Dissertation } \\
\text { Writing up } \\
\text { Next steps }\end{array}$ \\
\hline Activities & 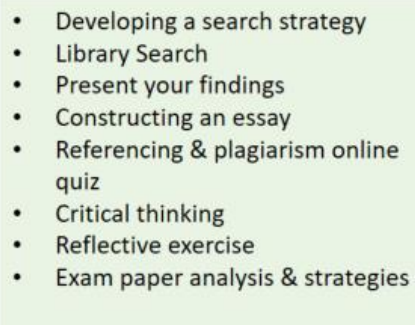 & 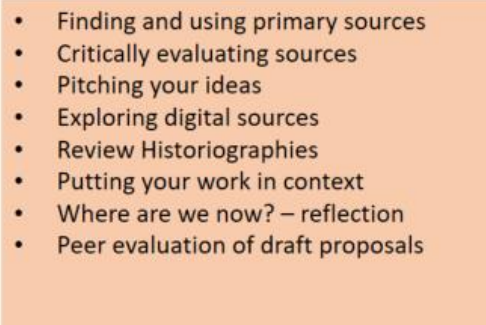 & $\begin{array}{l}\text { - Updating CVs (Peer evaluation) } \\
\text { TM \& O Questionnaire and } \\
\text { discussion } \\
\text { - } \text { Finding \& using resources } \\
\text { effectively } \\
\text { - Evaluation of posters } \\
\text { - Producing a poster (in Lab) } \\
\text { - } \text { Whanced Word skills } \\
\text { - Postgraduate options }\end{array}$ \\
\hline
\end{tabular}


Table 3. Photography case study.

\begin{tabular}{|c|c|c|c|}
\hline & Foundation & Intermediate & Final \\
\hline Module Title & $\begin{array}{l}\text { Photographic Theory and Practice ( } 40 \\
\text { credits) }\end{array}$ & Audiences and Context ( 40 credits) & Theory for Photography ( 40 credits) \\
\hline $\begin{array}{l}\text { Type of } \\
\text { Assessment }\end{array}$ & $\begin{array}{l}\text { Essay ( } 2250 \text { words) } \\
\text { Reflective Portfolio } \\
\text { Research summary }\end{array}$ & $\begin{array}{l}\text { Annotated Bibliography }(2,000) \\
\text { Essay }(3,500) \\
\text { Portfolio } \\
\text { Critical Research Summary }\end{array}$ & $\begin{array}{l}\text { Dissertation ( } 6,000 \text { words) } \\
\text { Professional Practice (Website and } \\
\text { blog) } \\
\text { Critical Evaluation } \\
\text { Verbal Presentation }\end{array}$ \\
\hline Session Title & $\begin{array}{l}\text { Information Sources, Strategies and } \\
\text { Referencing (Term 1) } \\
\text { Essay Writing Workshop (Term 2) }\end{array}$ & $\begin{array}{l}\text { Academic Research and Annotated Bibliographies } \\
\text { (Term 1) } \\
\text { Critical reading, note-taking and essay structure } \\
\text { (Term 2) }\end{array}$ & $\begin{array}{l}\text { Dissertation Proposal Workshop } \\
\text { (Term 1) } \\
\text { Dissertation Q\&A Clinic (Term 2) }\end{array}$ \\
\hline Activities & 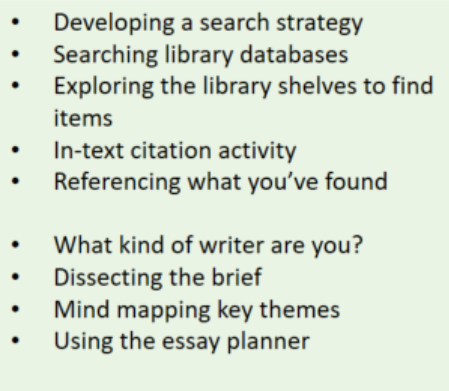 & $\begin{array}{l}\text { - Online quiz (https://kahoot.com/) - types of } \\
\text { research source } \\
\text { - Thematic search of library databases } \\
\text { - Exploring the library shelves to find items } \\
\text { - Creating an annotated bibliography entry } \\
\text { - Sharing source and entry in group discussion } \\
\text { - Group reading and discussion of journal article } \\
\text { - Annotating journal scrolls } \\
\text { - Essay planning with scrolls }\end{array}$ & $\begin{array}{l}\text { What does 'dissertation' mean } \\
\text { to you? } \\
\text { - Secondary sources - critical } \\
\text { review discussion } \\
\text { - Mind-mapping themes and } \\
\text { developing a researchable } \\
\text { question } \\
\text { - Translating research question } \\
\text { into aim and objectives } \\
\text { - From mind-map to linear } \\
\text { structure - thinking about } \\
\text { chapters }\end{array}$ \\
\hline
\end{tabular}

For both case studies, the sessions shown are learning development timetabled workshops which are embedded in the curriculum and delivered in collaboration with subject tutors, librarians, IT specialists or careers advisors. This collaboration was driven by student-need and the student voice was a major element in all aspects of curriculum development. The written tasks become more demanding throughout the student journey, requiring an increasing level of critical analysis. Alongside these workshops, learning developers continue to offer individual support through tutorials and drop-in sessions.

In History, the foundation year has a non-credit bearing module entitled 'Becoming a Historian' which has regular seminars with Personal Academic Tutors alongside the workshops. The work done in these sessions feeds in to the other foundation module assessments as formative work. The intermediate module is a 20 credit 'Research Skills' module and includes other subject specific content material and this can feed into the final year dissertation although there are obvious caveats about repetition. The final year sessions are part of a 40 credit module named 'History Dissertation and Graduate Futures' in which students take part in a research fair with posters that they have designed based on their dissertation topics and produce a 12,000-word dissertation. Alongside this, they have input from the university careers service and professionals in the field. 
Photography is structured slightly differently, particularly at foundation level, as the collaborative learning development input is within the theory modules of the course, which all have summative assessment and are credit bearing. Although Photography is a practical subject, an understanding and articulation of theory through critical reading and writing is an important element. As such, it is 'scaffolded' across the three years from an introduction to academic research, writing and referencing at foundation level, towards a more critical approach in the intermediate year through the use of scrolls to encourage active reading of challenging texts (Middlebrook, 2015) and an in depth research-led session in the final year.

The input into the History modules has been noted in the annual evaluation as an example of good practice: 'dedicated skills tutors who are integrated into the teaching programme . . . at all 3 levels'. As part of this evaluation, the second year History research module, in particular, has been recently adapted in relation to student feedback which called for more autonomy in topic choice. For photography students, the 'scrolling' session was highlighted as particularly enjoyable and useful. The course team are working with learning developers to continue to enrich the curriculum in innovative ways that make connections between art theory and creative practice, underpinned by critical reflection to help students recognise and articulate narratives of their own learning and progression.

\section{Conclusion}

The intermediate year has been shown to be neglected in favour of intense concentration on transition in the first year and outputs in the final year. A holistic approach to curriculum design and process means that the intermediate year can become a significant step in learning development which gives the student journey a clear sense of progression. Our focus group analysis demonstrated that the second year is complex in that students felt the need for more guidance whereas tutors were trying to foster more autonomous learners. Learning developers are ready to be part of a solution to these tensions, particularly through collaborative interventions. These voices were captured thematically in an online resource which can prompt ideas for progressive curriculum design. Two examples of curriculum design are used to illustrate different models of collaboration which have resulted in successful pathways for scaffolding student learning development. 
Proactively embedding learning development into a course requires a concerted effort from all stakeholders to work towards eradicating some elements of the 'second year blues', thus enabling students to achieve their potential in the final year.

\section{References}

ALDinHE (2014a) Progressive learning development. Available at: http://aldinheembeddingskills.hud.ac.uk/Progressive learning development (Accessed: 17 July 2018).

ALDinHE (2014b) Generic principles for integrating learning development into the curriculum. Available at: http://aldinhe-embeddingskills.hud.ac.uk/node/43 (Accessed: 20 October 2018).

Audacity (2018) Audacity: free, open source, cross-platform audio software (Version 2.3.0) [Audio software]. Available at: https://www.audacityteam.org/ (Accessed: 5 June 2018).

Bailey, R., Tinker, A. and Hill, P. (2013) 'Ensuring progression in learning development', Celebrating Learning Development: 10th ALDinHE Conference 2013, Plymouth University, Plymouth 25-27 March.

Barbour, R. (2007) Doing focus groups. SAGE: London.

Baxter-Magolda, M. B. (2006) 'Intellectual development in the college years', Change: The Magazine of Higher Learning, 38(3), pp. 50-54.

https://doi.org/10.3200/CHNG.38.3.50-54

Blake, J and Illingworth, S. (2015) 'Interactive and interdisciplinary student work: a facilitative methodology to encourage lifelong learning', Widening Participation and Online Learning, 17(2), pp. 108-118. https://doi.org/10.5456/WPLL.17.2SI.107 
Braun, V. and Clarke, V. (2006) 'Using thematic analysis in psychology', Qualitative Research in Psychology, 3(2), pp. 77-101. https://doi.org/10.1191/1478088706qp063oa

Cacciolatti, L., Lee, S. H. and Molinero, C. M. (2017) 'Clashing institutional interests in skills between government and industry: an analysis of demand for technical and soft skills of graduates in the UK', Technological Forecasting and Social Change, 119, pp. 139-153. https://doi.org/10.1016/j.techfore.2017.03.024

Cassar, A., Funk, R., Hutchings, D., Henderson, F. and Pancini, G. (2012) 'Student transitions - evaluation of an embedded skills approach to scaffolded learning in the nursing curriculum', The International Journal of the First Year in Higher Education, 3(1), 35-48. https://doi.org/10.5204/intjfyhe.v3i1.102

Clughen, L. and Connell, M. (2011) 'Writing and resistance: reflections on the practice of embedding writing in the curriculum', Arts and Humanities in Higher Education, 11(4), pp. 333-335. https://doi.org/10.1177/1474022211429543

Colucci, E. (2007) 'Focus groups can be fun: the use of activity-oriented questions in focus group discussions', Qualitative Health Journal, 17(10), pp. 1422-1433. https://doi.org/10.1177/1049732307308129

Fifth Planet Productions (2016) Fifth Planet. Available at: http://www.fifthplanet.org/ (Accessed: 17 July 2018).

Gump, S. E. (2007) 'Classroom research in a general education course: exploring implications through an investigation of the sophomore slump' The Journal of General Education, 56(2), pp. 105-125. https://doi.org/10.1353/jge.2007.0020

Hathaway, J. (2015) 'Developing that voice: locating academic writing tuition in the mainstream of higher education' Teaching in Higher Education, 20(5), pp. 506-517. https://doi.org/10.1080/13562517.2015.1026891 
Higher Education Academy (2018) Graduate attributes framework. Available at:

https://www.heacademy.ac.uk/knowledge-hub/graduate-attributes-framework (Accessed: 4 July 2018).

Hill, P., Tinker, A. and Catterall, S. (2010) 'From deficiency to development: the evolution of academic skills provision at one UK university' Journal of Learning Development in Higher Education, Issue 2, February, pp. 1-19.

Hill, P. and Tinker, A. (2013) 'Integrating learning development into the student experience' Journal of Learning Development in Higher Education, Issue 5, March, pp. 1-18.

Huddersfield University (2014) Progressive learning development - intro. Embedding Skills Teaching and Learning Project, Huddersfield University, 15 April [Video]. Available at:

https://www.youtube.com/watch?v=ke6dlqvawxw\&index=2\&list=PLzuejZvzpIS5mJT 2MvMi2HaJNC6P0X8R1 (Accessed: 24 October 2018).

Hunter, M. S., Tobolowsky, B. F., Gardner, J. N., Evenbeck, S. E., Pattengale, J. A., Schaller, M. and Schreiner, L. A. (2010) Helping sophomores succeed: understanding and improving the second-year experience. San Francisco: JosseyBass.

Ivanic, R. and Lea, M. R. (2006) 'New contexts, new challenges: the teaching of writing in UK higher education', in Ganobcsik-Williams, L. (ed.) Teaching academic writing in UK higher education: theories, practice and models. London: Palgrave/Macmillan.

Krueger, R.A. and Casey, M.A. (2009) Focus groups. a practical guide for applied research. $4^{\text {th }}$ edn. London: Sage Publications.

Liverpool John Moores University (2013) The forgotten year: tackling the sophomore slump. Available at: http://secondyearexperience.ljmu.ac.uk/ (Accessed: 4 July 2018). 
MacLellan, E. (2001) 'Assessment for learning: the differing perceptions of tutors and students', Assessment and Evaluation in Higher Education, 26(4), pp. 307-318. https://doi.org/10.1080/02602930120063466

Middlebrook, D. (2015) Unrolling the book: Why use scrolls? A brief introduction to the benefits of using scrolls for classroom instruction. Available at: http://www.textmapping.org/whyUseScrolls.pdf (Accessed: 17 July 2018).

Miles, M. B. and Huberman, A.M. (1994) An expanded sourcebook: qualitative data analysis. London: Sage Publications.

Milsom, C., Stewart, M., Yorke, M. and Zaitseva, E. (eds.) (2015) Stepping up to the second year at university: academic, psychological and social dimensions. London: Routledge.

Rabiee, F. (2004) 'Focus-group interview and data analysis', Proceedings of the Nutrition Society, 63(4), pp. 655-660. https://doi.org/10.1079/PNS2004399

Ritchie, J. and Spencer, L. (1994) 'Qualitative data analysis for applied policy research', in Bryman, A. and Burgess, R. G. (eds.) Analyzing qualitative data. London: Routledge pp. 173-194.

Rust, C. (2016) Shifting the focus from skills to 'graduateness', Phoenix (the AGCAS: Association of Graduate Careers Advisory Services Journal), 148, pp. 8-10.

Scott, J. and Cashmore, A. (2012) Fragmented transitions: moving to the 2nd year. Proceedings STEM Annual Conference. Available at: https://www.heacademy.ac.uk/knowledge-hub/fragmented-transitions-moving2nd-year (Accessed: 18 July 2018).

Skills@Library, University of Leeds (n.d.) Second year success. Available at: https://resources.library.leeds.ac.uk/second-year-success/thisyear.html (Accessed: 18 July 2018). 
Squires, P., Tinker A. and Redmore, N. (2009) 'Reflect, understand and plan: an integrated learning portfolio', in Wade, S. and Walton, K. (eds.) Futurescan: Mapping the Territory: Association of Fashion and Textile Courses Conference, University of Liverpool, 17-18 November 2009, pp.100-109 [Online]. Available at: http://eprints.hud.ac.uk/id/eprint/10688/ (Accessed: 19 July 2018).

Thompson, T., Milsom, C., Zaitseva, E., Stewart, M., Darwent, S. and Yorke, M. (2013) The Forgotten Year? Tackling the Second Year Slump, The Higher Education Academy. Available at:

https://www.heacademy.ac.uk/system/files/projects/liverpool john moores ntfs 20 10 project final report.pdf (Accessed: 18 July 2018).

Tobolowsky, B. (2008) 'Sophomores in transition: the forgotten year', New Directions for Higher Education, 144, pp. 59-67. https://doi.org/10.1002/he.326

Wall, A. (2006) 'Introduction', in Davies, S., Swinburne, D. and Williams, G. (eds.) Writing matters: the Royal Literary Fund report on student writing in higher education. London: Royal Literary Fund.

Webb, O. J. and Cotton, D. R. E. (2018) 'Deciphering the sophomore slump: changes to student perceptions during the undergraduate journey', Higher Education, pp. 1-18. https://doi.org/10.1007/s10734-018-0268-8

Whittle S. R. (2018) 'The second-year slump - now you see it, now you don't: using DREEM-S to monitor changes in student perception of their educational environment', Journal of Further and Higher Education, 42(1), pp. 92-101. https://doi.org/10.1080/0309877X.2016.1206854

Wingate, U. (2006) 'Doing away with 'study skills”, Teaching in Higher Education, 11(4), pp. 457-469. https://doi.org/10.1080/13562510600874268

Yorke, M. (2015) 'Why study the second year?', in Milsom, C., Stewart, M., Yorke, M. and Zaitseva, E. (eds.) Stepping up to the second year at university: academic, psychological and social dimensions. London: Routledge, pp. 1-13. 


\section{Author details}

Dr Pat Hill is a Senior Lecturer and Academic Skills Tutor in the School of Music, Humanities and Media at the University of Huddersfield.

Dr Amanda Tinker is a Senior Lecturer and Academic Skills Tutor in the School of Art, Design and Architecture at the University of Huddersfield. 